\title{
Дифференцированный ввод кормовых бобов в комбикорма для цыплят-бройлеров
}

Яцышина М.М., аспирант

ФГБНУ Федеральный научный центр «Всероссийский научно-исследовательский и технологический институт птицеводства» Российской академии наук (ФНЦ «ВНИТИП» РАН)

\begin{abstract}
Аннотащия: В опыте на 5 группах бройлеров Кобб-500 (1-37 дней жизни, 35 голоб б группе) определена эффрективность дифрферениированного 6 забисимости от возраста вбода 6 комбикорма кормобых бобов сорта Узуновские. Контрольная группа 1 получала сбалансированные рационы без бобов; опитнные группи получали рационы с вбодом бобов в количестве 2,5; 5,0; 7,5 и 10,0\% в возрасте 5-21 день (ростовой рацион) и 5,0; 10,0; 15,0 и 20,0\% в возрасте 22-37 дней (финишный рацион) соответственно группам 2-5. Установлено, что 6 группах 2-4 средняя живая масса 21-днебных бройлеров была быше, чем 6 контрольной группе, на 3,5; 2,8 и 1,9\% соответственно; 6 группе 5 она была на уровне контроля. В 37 дней 6 группах 2 и 3 живая масса была быше контроля на 3,1 и 1,3\% соответственно, 6 группе 4 - на уровне контроля, 6 группе 5 - на 3,0\% ниже. Конберсия корма следовала аналогичной тендениии: 6 группах 2 и 3 она была ниже контроля на 0,4\%, 6 группе 4 - на уробне контроля, 6 группе 5 - на 3,6\% быше, что было, по-бидимому, сбязано со снижением переваримости и использобания питательных беществ корма из-за бысокого со-

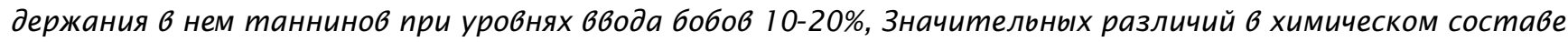
грудных и ножных мыши бройлеров, а также содержании витаминов 6 печени между группами отмечено не было. Сделано заключение, что рациональными уровнями кормобых бобов 6 комбикормах для бройлеров следует считать 7,5\% до 21 -дневного бозраста и 15\% - с 22 дня и до кониа откорма. Более бысокое содержание кормовых бобов снижает продуктивность птицы.
\end{abstract}

Ключебые слоба: кормобые бобы, комбикорма, бройлеры, жибая масса, конберсия корма, питательные вемества.

Введение. Птицеводческая отрасль является мощным потребителем кормов, и комбикормовая промышленность испытывает острый дефицит основного сырья, в первую очередь, источников протеина. В России, как и во всем мире, все больший интерес вызывают альтернативные источники растительного белка, в частности, такая ценная зернобобовая культура, как кормовые бобы $[6,10]$. Кормовые бобы занимают первое место среди зерновых и зернобобовых по общему сбору переваримого белка с 1 га [1]. Семена бобов содержат 26-34\% белка, 0,8-1,5\% жира, 50-55\% углеводов. Благодаря широкой генетической вариации кормовые бобы в настоящее время выращивают более чем в 30 странах как пищевую и кормовую культуру. Широкое распространение бобы получили в Китае, где площадь под их возделывание составляет более 1 млн га (55\% мировых площадей) $[3,4,9]$. В России, по данным 2014 г., посевы кормовых бобов составили всего 6,4 тыс. га [3,8].

Основным фактором, ограничивающим использование кормовых бобов, является наличие в них антипитательных веществ, в частности таннинов. Поэтому перед применением кормовых бобов в рационах для сельскохозяйственной птицы рекомендуют проводить их предварительную обработку (шелушение, экстру- дирование, автоклавирование, гранулирование, тостирование, микронизацию, обработку химическими веществами, включая органические кислоты) $[2,5,7]$. Не стоит забывать и о таком методе снижения содержания антипитательных веществ, как сортовыведение. В настоящее время выведены нулевые по содержанию таннинов сорта кормовых бобов $[11,12]$.

По данным зарубежных специалистов, В рационы цыплятбройлеров можно включать до 20\% кормовых бобов при условии обогащения их метионином, лизином и триптофаном [9-1 1, 13] По рекомендациям ВНИТИП, уровень ввода кормовых бобов в ра- 
ционы для взрослой птицы составляет 7\% [6].

Целью исследований являлось определение рациональных уровней дифференцированного ввода кормовых бобов сорта Узуновские в рационы цыплят-бройлеров в разные периоды выращивания.

Материал и методика исследований. Исследования выполняли в отделе питания ФНЦ «ВНИТИП» РАН и на базе вивария СГЦ « Загорское ЭПХ» на бройлерах кросса Кобб-500 с суточного до 37-дневного возраста. Цыплят содержали в клеточных батареях типа R-15, по 35 голов в каждой группе. Плотность посадки, световой, температурный, влажностный режимы, фронт кормления и поения, а также зоогигиенические требования во всех возрастных периодах птицы соответствовали рекомендациям ВНИТИП и для всех групп были одинаковыми. Корм и воду цыплята получали вволю.
Таблица 1. Схема опыта на бройлерах с дифференцированным вводом кормовых бобов в рационы

\begin{tabular}{|c|c|c|}
\hline \multirow{2}{*}{ Группа } & \multicolumn{2}{|c|}{ Особенности кормления по возрастам цыплят } \\
\hline & 5-21 день & с 22 дня до конца выращивания \\
\hline $1 \mathrm{k}$ & $\begin{array}{l}\text { Полнорационный комбикорм (ОР) } \\
\text { с питательностью, соответствующей } \\
\text { рекомендациям для кросса }\end{array}$ & $\begin{array}{l}\text { Полнорационный комбикорм (OP) } \\
\text { с питательностью, соответствующей } \\
\text { рекомендациям для кросса }\end{array}$ \\
\hline 2 & ОР с 2,5 \% кормовых бобов & ОР с 5,0 \% кормовых бобов \\
\hline 3 & ОР с 5,0 \% кормовых бобов & ОР с 10,0 \% кормовых бобов \\
\hline 4 & ОР с 7,5\% кормовых бобов & ОР с 15,0\% кормовых бобов \\
\hline 5 & ОР с 10,0\% кормовых бобов & ОР с $20,0 \%$ кормовых бобов \\
\hline
\end{tabular}

Кормление бройлеров осуществляли в две фазы: 5-21 день - ростовой период и с 22 дня до конца выращивания - финишный (первые 5 дней цыплята всех групп получали одинаковые гранулированные престартерные комбикорма). Питательность комбикормов соответствовала рекомендациям ВНИТИП, они были выровнены по содержанию питательных веществ. Схема опыта представлена в табл. 1.

Физиологические (балансовые) опыты по определению переваримости и доступности пи- тательных веществ рациона проводили на петушках-бройлерах в возрасте 30 дней. В 37-дневном возрасте по 3 головы из каждой группы было убито для проведения анатомической разделки и химических анализов; определяли убойный выход и выход грудных мышц (в \% к массе потрошеной тушки), абсолютную и относительную массу некоторых внутренних органов; химический состав грудных и ножных мышц, а также содержание некоторых витаминов в печени.

\section{Таблица 2. Зоотехнические показатели опыта}

\begin{tabular}{|c|c|c|c|c|c|}
\hline \multirow{2}{*}{ Показатели } & \multicolumn{5}{|c|}{ Группа } \\
\hline & $1 \mathbf{k}$ & 2 & 3 & 4 & 5 \\
\hline Живая масса (г) в возрастах: суточном & $\begin{array}{c}42,4 \\
\pm 0,34\end{array}$ & $\begin{array}{c}42,6 \\
\pm 0,43\end{array}$ & $\begin{array}{c}42,6 \\
\pm 0,36\end{array}$ & $\begin{array}{c}42,5 \\
\pm 0,43\end{array}$ & $\begin{array}{c}42,3 \\
\pm 0,34\end{array}$ \\
\hline \% к контролю & - & 100,4 & 100,5 & 100,2 & 99,7 \\
\hline 14-дневном & $\begin{array}{l}405,8 \\
\pm 6,00\end{array}$ & $\begin{array}{l}417,8 \\
\pm 5,61\end{array}$ & $\begin{array}{l}414,3 \\
\pm 7,04\end{array}$ & $\begin{array}{l}410,9 \\
\pm 5,92\end{array}$ & $\begin{array}{l}407,2 \\
\pm 8,14\end{array}$ \\
\hline \% к контролю & - & 103,0 & 102,1 & 101,3 & 100,3 \\
\hline 21-дневном & $\begin{array}{c}793,1 \\
\pm 10,59\end{array}$ & $\begin{array}{c}820,9 \\
\pm 12,33\end{array}$ & $\begin{array}{r}815,6 \\
\pm 12,43\end{array}$ & $\begin{array}{r}807,9 \\
\pm 11,26\end{array}$ & $\begin{array}{c}791,1 \\
\pm 11,18\end{array}$ \\
\hline \% к контролю & - & 103,5 & 102,8 & 101,9 & 99,8 \\
\hline 37-дневном, в среднем & 2122,1 & 2187,5 & 2149,0 & 2114,4 & 2059,3 \\
\hline \% к контролю & - & 103,1 & 101,3 & 99,6 & 97,0 \\
\hline в т.ч. курочки & $\begin{array}{l}2007,7 \\
\pm 23,05\end{array}$ & $\begin{array}{c}2072,9 \\
\pm 22,37^{*}\end{array}$ & $\begin{array}{l}2022,3 \\
\pm 37,08\end{array}$ & $\begin{array}{r}1993,9 \\
\pm 22,35\end{array}$ & $\begin{array}{r}1944,0 \\
\pm 22,87^{\prime}\end{array}$ \\
\hline \% к контролю & - & 103,2 & 100,7 & 99,3 & 96,8 \\
\hline в т.ч. петушки & $\begin{array}{l}2236,5 \\
\pm 29,20\end{array}$ & $\begin{array}{c}2302,0 \\
\pm 22,32 *\end{array}$ & $\begin{array}{l}2275,6 \\
\pm 37,86\end{array}$ & $\begin{array}{l}2234,8 \\
\pm 24,23\end{array}$ & $\begin{array}{l}2174,6 \\
\pm 24,03\end{array}$ \\
\hline \% к контролю & - & 102,9 & 101,7 & 99,9 & 97,2 \\
\hline Среднесуточный прирост, г & 56,2 & 58,0 & 56,9 & 56,0 & 54,5 \\
\hline \% к контролю & - & 103,2 & 101,2 & 99,6 & 97,0 \\
\hline Потребление корма, кг/гол. & 3,51 & 3,60 & 3,54 & 3,50 & 3,53 \\
\hline \% к контролю & - & 102,6 & 100,9 & 99,7 & 100,6 \\
\hline Затраты корма на 1 кг прироста живой ассы, кг & 1,69 & 1,68 & 1,68 & 1,69 & 1,75 \\
\hline \% к контролю & - & 99,4 & 99,4 & 100,0 & 103,6 \\
\hline
\end{tabular}

Различия с контролем достоверны при *P<0,05. 


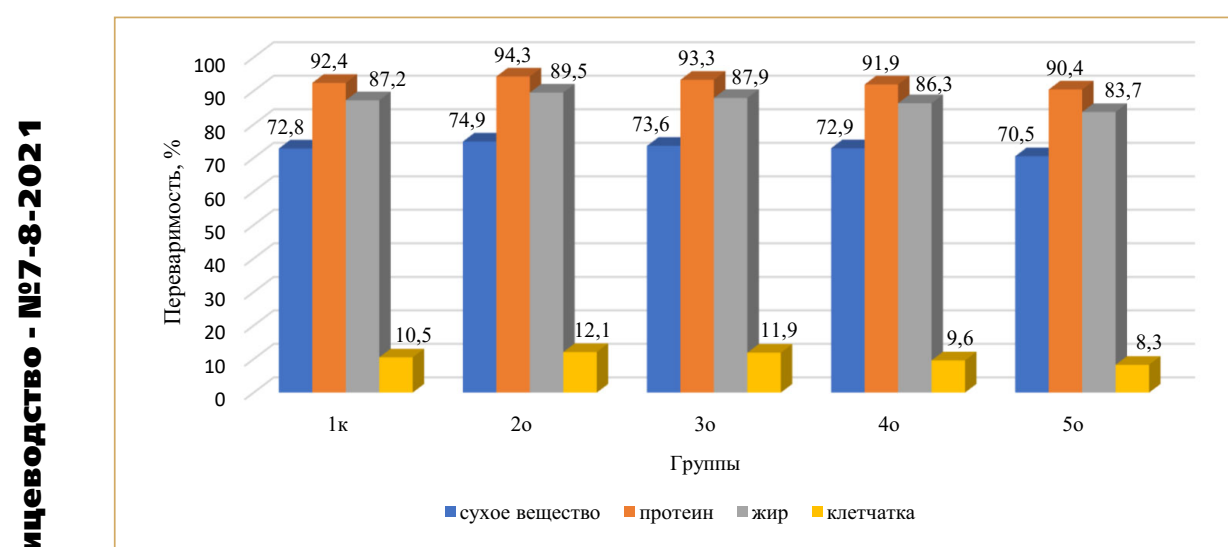

Рисунок 1. Переваримость питательных веществ корма

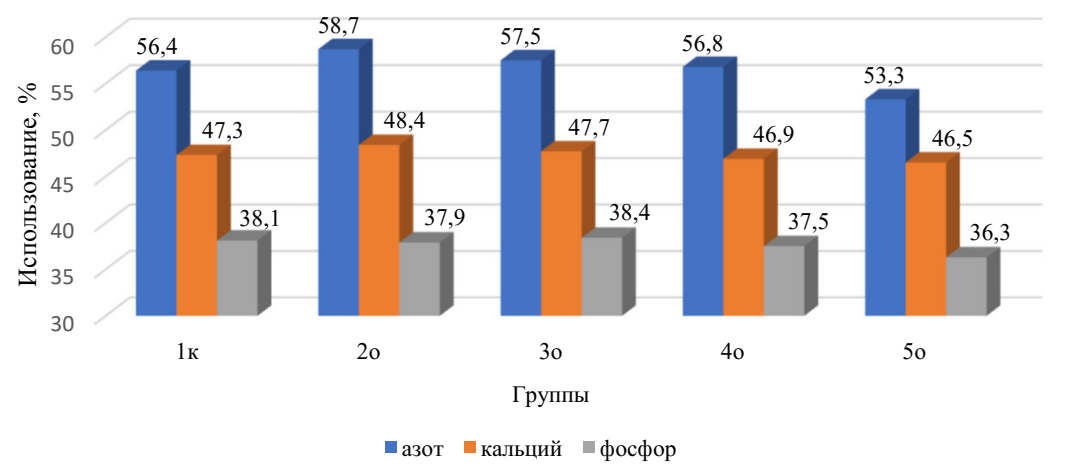

Рисунок 2. Использование питательных веществ корма

\begin{tabular}{|c|c|c|c|c|c|}
\hline \multirow{2}{*}{ Показатель } & \multicolumn{5}{|c|}{ Группа } \\
\hline & $1 \mathrm{k}$ & 2 & 3 & 4 & 5 \\
\hline $\begin{array}{l}\text { Кивая масса } \\
\text { Ітицы, г }\end{array}$ & $\begin{array}{l}2246,7 \\
\pm 15,28\end{array}$ & $\begin{array}{c}2303,3 \\
\pm 4,08\end{array}$ & $\begin{array}{l}2263,3 \\
\pm 12,02\end{array}$ & $\begin{array}{c}2226,7 \\
\pm 2,89\end{array}$ & $\begin{array}{l}2180,0 \\
\pm 15,49\end{array}$ \\
\hline Иасса потрошеной тушки, г & $\begin{array}{l}1601,9 \\
\pm 15,98\end{array}$ & $\begin{array}{c}1656,1 \\
\pm 9,01\end{array}$ & $\begin{array}{l}1618,3 \\
\pm 19,71\end{array}$ & $\begin{array}{l}1581,0 \\
\pm 9,54\end{array}$ & $\begin{array}{l}1519,5 \\
\pm 18,51\end{array}$ \\
\hline бойный выход, \% & 71,3 & 71,9 & 71,5 & 71,0 & 69,7 \\
\hline $\begin{array}{l}\text { ыход грудных мышц, \% от массы } \\
\text { отрошеной тушки }\end{array}$ & 23,4 & 24,0 & 23,5 & 23,1 & 22,8 \\
\hline
\end{tabular}

\begin{tabular}{|c|c|c|c|c|c|}
\hline \multirow{2}{*}{ Показатель } & \multicolumn{5}{|c|}{ Гpynna } \\
\hline & 1 к & 2 & 3 & 4 & 5 \\
\hline Масса мышечного желудка, г & $\begin{array}{l}26,27 \\
\pm 0,60\end{array}$ & $\begin{array}{l}27,53 \\
\pm 0,30\end{array}$ & $\begin{array}{l}27,33 \\
\pm 0,76\end{array}$ & $\begin{array}{l}26,67 \\
\pm 0,22\end{array}$ & $\begin{array}{l}26,00 \\
\pm 0,70\end{array}$ \\
\hline Относительная масса, \% & 0,012 & 0,012 & 0,012 & 0,012 & 0,012 \\
\hline Масса печени, г & $\begin{array}{l}47,03 \\
\pm 0,98\end{array}$ & $\begin{array}{l}47,57 \\
\pm 0,69\end{array}$ & $\begin{array}{l}47,80 \\
\pm 0,47\end{array}$ & $\begin{array}{l}46,87 \\
\pm 0,72\end{array}$ & $\begin{array}{l}46,50 \\
\pm 0,50\end{array}$ \\
\hline Относительная масса, \% & 0,021 & 0,021 & 0,021 & 0,021 & 0,021 \\
\hline Масса сердца, г & $\begin{array}{l}11,57 \\
\pm 0,32\end{array}$ & $\begin{array}{l}12,10 \\
\pm 0,12\end{array}$ & $\begin{array}{l}11,47 \\
\pm 0,32\end{array}$ & $\begin{array}{l}10,90 \\
\pm 0,23\end{array}$ & $\begin{array}{l}10,73 \\
\pm 0,22\end{array}$ \\
\hline Относительная масса, \% & 0,005 & 0,005 & 0,005 & 0,005 & 0,005 \\
\hline
\end{tabular}

Результаты исследований и их обсуждение. Зоотехнические результаты опыта представлены в табл. 2. Сохранность поголовья во всех группах составила 100\%. Живая масса 21-дневных бройлеров в опытных группах 2-4 была выше, чем в контроле, на 3,5; 2,8 и 1,9\% соответственно, в группе 5 была на уровне контроля.

Увеличение уровней кормовых бобов в 2 раза в последующий возрастной период обеспечило получение живой массы на $3,1 \%$ выше контроля в опытной группе 2, в том числе курочек на $3,2 \%(\mathrm{P}<0,05)$, петушков - на $2,9 \%(P<0,05)$. В опытной группе 3 живая масса птицы была на 1,3\% выше, чем в группе 1, в том числе курочек - на 0,7\%, петушков на 1,7\%. Последующее увеличение количества кормовых бобов до 15\% (группа 4) способствовало получению живой массы бройлеров на уровне контроля; увеличение до 20\% (группа 5) снижало ее на 3,0\%, в том числе курочек - на $3,2 \%$ ( $<<0,05)$, петушков - на 2,8\%. Среднесуточный прирост живой массы следовал аналогичной закономерности.

По потреблению корма между группами значительных различий не отмечено, за исключением группы 2, где она была выше контроля на 2,6\%. При этом затраты корма на 1 кг прироста живой массы во всех группах не превышали показатель контроля, лишь в группе 5 они были выше на 3,6\%.

Результаты балансового опыта (рис. 1 и 2) свидетельствуют о том, что переваримость и использование питательных веществ корма бройлерами зависели от уровней использования кормовых бобов. Так, в группах 2 и 3 отмечалась тенденция по улучшению переваримости сухого вещества корма на 0,8-2,1\%, протеина - на 0,9$1,9 \%$, жира - на 0,7 и 2,3\%. По 
мере увеличения уровней кормовых бобов до 15\% (группа 4) во второй период выращивания цыплят данные показатели были на уровне контроля. Скармливание 20\% кормовых бобов (группа 5) способствовало снижению данных показателей на 2,3; 2,0 и 3,5\% соответственно по сравнению с контролем; переваримость клетчатки также была минимальной - на 2,2\% ниже, чем в контроле. Аналогичная тенденция наблюдалась и по использованию азота корма.

Использование кальция и фосфора между группами не имело значительных расхождений, лишь в группе 5 наметилась тенденция к ухудшению этих показателей.

Использование максимальных уровней кормовых бобов в комбикормах отразилось на некотором снижении убойного выхода (на 1,6\%) и выхода грудных мышц (на 0,6\%) в группе 5 (табл. 3).

По абсолютным и особенно относительным (к живой массе) массам мышечного желудка, печени и сердца между группами разницы не было (табл. 4), они были в пределах физиологической нормы.

Значительных различий в химическом составе грудных и ножных мышц цыплят всех групп также не отмечено (табл. 5 и 6).

Содержание витаминов А, Е и $\mathrm{B}_{2}$ в печени цыплят находилось В пределах физиологической нормы и не зависело от уровня кормовых бобов в рационе (табл. 7).

Заключение. Таким образом, из результатов опыта следует, что рациональным дифференцированным уровнем ввода кормовых бобов в комбикорма для бройлеров следует считать 7,5\% до 21-дневного возраста и 15\% с 22 дня и до конца откорма. Более высокие количества снижают продуктивность птицы.
Таблица 5. Содержание протеина, жира и аминокислот в грудных мышцах бройлеров (на естественную влажность), \%

\begin{tabular}{lccccc} 
& \multicolumn{5}{c}{ Группа } \\
\cline { 2 - 6 } \multicolumn{1}{c}{ Показатель } & $\mathbf{1}$ & $\mathbf{2}$ & $\mathbf{3}$ & $\mathbf{4}$ & $\mathbf{5}$ \\
\hline Протеин & 21,61 & 22,57 & 22,30 & 22,10 & 21,57 \\
\hline Жир & 0,90 & 0,86 & 0,96 & 0,85 & 0,96 \\
\hline Аминокислоты: лизин & 1,64 & 1,56 & 1,59 & 1,70 & 1,75 \\
\hline Гистидин & 1,01 & 1,02 & 1,01 & 1,15 & 1,04 \\
\hline Аргинин & 1,61 & 1,35 & 1,44 & 1,44 & 1,51 \\
\hline Аспарагиновая кислота & 1,66 & 1,67 & 1,67 & 1,78 & 1,74 \\
\hline Треонин & 0,79 & 0,86 & 0,82 & 0,86 & 0,85 \\
\hline Серин & 0,69 & 0,75 & 0,74 & 0,78 & 0,77 \\
\hline Глутаминовая кислота & 3,06 & 2,90 & 2,99 & 3,15 & 3,07 \\
\hline Пролин & 1,21 & 0,99 & 1,00 & 0,97 & 0,91 \\
\hline Глицинн & 0,81 & 0,75 & 0,80 & 0,84 & 0,77 \\
\hline Аланин & 1,01 & 1,06 & 1,04 & 1,10 & 1,09 \\
\hline Цистин & 0,20 & 0,22 & 0,19 & 0,21 & 0,21 \\
\hline Валин & 0,81 & 0,89 & 0,84 & 0,92 & 0,90 \\
\hline Метионин & 0,56 & 0,60 & 0,56 & 0,57 & 0,57 \\
\hline Изолейцин & 0,85 & 0,81 & 0,80 & 0,86 & 0,78 \\
\hline Лейцин & 1,42 & 1,38 & 1,37 & 1,54 & 1,44 \\
\hline Тирозин & 0,78 & 0,71 & 0,65 & 0,70 & 0,78 \\
\hline Фенилаланин & 0,87 & 0,72 & 0,72 & 0,77 & 0,70 \\
\hline Сумма аминокислот & 18,99 & 18,25 & 18,24 & 19,35 & 18,86 \\
\hline Незаменимые аминокислоты & 9,57 & 9,19 & 9,16 & 9,82 & 9,54 \\
\hline Заменимые аминокислоты & 9,43 & 9,06 & 9,07 & 9,53 & 9,32 \\
\hline Соотношение незаменимые/заменимые & 1,02 & 1,01 & 1,01 & 1,03 & 1,02 \\
\hline & & & & & \\
\hline
\end{tabular}

Таблица 6. Содержание протеина, жира и аминокислот в ножных мышцах бройлеров (на естественную влажность), \%

\begin{tabular}{lccccc} 
& \multicolumn{5}{c}{ Пруппа } \\
\cline { 2 - 6 } & $\mathbf{1}$ & $\mathbf{2}$ & $\mathbf{3}$ & $\mathbf{4}$ & $\mathbf{5}$ \\
\hline Протеин & 19,55 & 18,83 & 18,64 & 19,12 & 18,15 \\
\hline Жир & 2,53 & 2,39 & 2,34 & 2,21 & 2,74 \\
\hline Аминокислоты & 1,27 & 1,31 & 1,26 & 1,38 & 1,37 \\
\hline Гистидин & 0,56 & 0,57 & 0,56 & 0,61 & 0,59 \\
\hline Аргинин & 1,04 & 1,12 & 1,00 & 1,15 & 1,11 \\
\hline Аспарагиновая кислота & 1,19 & 1,32 & 1,26 & 1,35 & 1,31 \\
\hline Треонин & 0,76 & 0,74 & 0,67 & 0,72 & 0,66 \\
\hline Серин & 0,63 & 0,65 & 0,59 & 0,61 & 0,61 \\
\hline Глутаминовая кислота & 2,57 & 2,61 & 2,59 & 2,85 & 2,73 \\
\hline Пролин & 0,79 & 0,71 & 0,74 & 0,71 & 0,75 \\
\hline Глицин & 0,72 & 0,71 & 0,67 & 0,69 & 0,68 \\
\hline Аланин & 0,80 & 0,86 & 0,82 & 0,86 & 0,84 \\
\hline Цистин & 0,16 & 0,15 & 0,14 & 0,17 & 0,17 \\
\hline Валин & 0,66 & 0,71 & 0,70 & 0,71 & 0,71 \\
\hline Метионин & 0,46 & 0,43 & 0,45 & 0,49 & 0,48 \\
\hline Изолейцин & 0,67 & 0,68 & 0,70 & 0,74 & 0,71 \\
\hline Лейцин & 1,21 & 1,19 & 1,16 & 1,22 & 1,20 \\
\hline Тирозин & 0,57 & 0,55 & 0,56 & 0,55 & 0,58 \\
\hline Фенилаланин & 0,60 & 0,62 & 0,65 & 0,67 & 0,71 \\
\hline Сумма аминокислот & 14,65 & 14,93 & 14,52 & 15,48 & 15,20 \\
\hline Незаменимые аминокислоты & 7,23 & 7,38 & 7,16 & 7,69 & 7,54 \\
\hline Заменимые аминокислоты & 7,42 & 7,55 & 7,36 & 7,79 & 7,66 \\
\hline Соотношение незаменимые/заменимые & 0,98 & 0,98 & 0,97 & 0,99 & 0,98 \\
\hline & & & & & \\
\hline
\end{tabular}


Таблица 7. Содержание витаминов в печени бройлеров, мкг/г

\begin{tabular}{cccccc}
\hline Витамины & \multicolumn{5}{c}{ Группа } \\
\cline { 2 - 6 } & $\mathbf{1 k}$ & $\mathbf{2}$ & $\mathbf{3}$ & $\mathbf{4}$ & $\mathbf{5}$ \\
\hline $\mathrm{A}$ & 153,57 & 149,83 & 143,54 & 151,76 & 154,96 \\
\hline $\mathrm{E}$ & 8,25 & 8,88 & 9,25 & 9,70 & 8,12 \\
\hline $\mathrm{B}_{2}$ & 11,21 & 11,40 & 11,18 & 11,02 & 11,88 \\
\hline
\end{tabular}

\section{Литература}

1. Вороничев Б.А., Коломейченко В.В. Кормовые бобы - надежный резерв увеличения производства растительного белка // Кормопроизводство. 2003. - №5. - С. 14-18.

2. Горлов И.Ф. [и др.] Новый метод снижения содержания антипитательных веществ в бобовых культурах // Вестник рос. с.-х. науки. - 2018. №3. - C. 71-73.

3. Задорин А.М., Ворониев Б.А., Ятчук П.В., Кудрявцев А.Н. Новый сорт кормовых бобов Красный богатырь // Зернобобовые и крупяные культуры. - 2016. - №3. - С. 85-89.

4. Кассамединов А.И., Разумовская Р.Г. Повышение питательной ценности кормов, применяемых в птицеводстве // Вестник АГТУ. - 2008. - №3. - С. 110 114.

5. Курчаева Е.Е., Черняева С.Н., Сафонова Ю.А. Изучение процесса снижения антипитательных веществ в семе- нах бобовых // Агроэкологический вестник. - 2017. - С. 132-137.

6. Фисинин В.И., Имагнулов Ш.А., Егоров И.А., Околелова, Т.М. [и др.] Рекомендации по кормлению сельскохозяйственной птицы. - Сергиев Посад: ВНИТИП, 2006. - 110 с.

7. Фицев А.И. Повышение качества и эффективности использования зерна бобовых в рационах сельскохозяйственных животных / Обзор.информ. Всерос. НИИ информ. и техн.-экон. исслед. агропром. комплекса; Сер. Животноводство, ветеринария и кормление с.-х. животных. - М., 1992. C. 4-21.

8. Чекмарев П.А., Артюхов А.И. Рациональные подходы к решению проблемы белка в России // Достижения науки и техники АПК. - 2011 . - №6. - С. 5-8. 9. Crepon K. Nutritional value of legumes (pea and faba beans) and economics of their use. In: Recent Advances in Animal Nutrition (Garnsworthy P.C. and Wise- man J., Eds.). Nottingham Univ. Press, Nottingham, UK, 2006. Pp. 332-366.

10. Diaz D., Morlacchini M., Masoero F., Moschini M. [et al.] Pea seeds (Pisum sativum), faba beans (Vicia faba var. minor) and lupin seeds (Lupinus albus var. multitalia) as protein sources in broiler diets: effect of extrusion on growth performance // Ital. J. Anim. Sci. - 2006. V. 5. - P. 43-53.

11. Koivunen E., Tuunainen P., Rossow L., Valaja J. Digestibility and utilization of faba bean (Vicia faba L.) diets in broiler // Acta Agric. Scand. A. 2014. - V. 64, No 4. - P. 217-225.

12. Zong X., Yang T., Liu R. Faba bean (Vicia Faba L.) breeding // In: Advances in Plant Breeding Strategies: Legumes, 2019. P. 245-286.

13. Witten S., Grashorn M., Aulrich K. Precaecal digestibility of crude protein and amino acids of a field bean (Vicia faba L.) and a field pea (Pisum sativum L.) variety for broilers // Anim. Feed Sci. Technol. - 2018. - V. 243. - P. 35-40.

\section{Для контакта с автором:}

Яцышина (Балдина)

Мария Михайловна

E-mail: baldina84@mail.ru

\title{
Age Dependent Supplementation of Diets for Broilers with Faba Beans Uzunovskie
}

\author{
Yatsyshina M.M.

\begin{abstract}
Federal Scientific Center "All-Russian Research and Technological Institute of Poultry" of Russian Academy of Sciences
\end{abstract}

Summary: The efficiency of age dependent supplementation of diets with faba beans (Uzunovskie variety) was studied on 5 treatments of Cobb-500 broilers (35 birds per treatment). All treatments were fed similar prestarter diet since 1 to 4 days of age. Control treatment 1 was fed balanced grower (5-21 days) and finisher (22-37 days) diets with soybean meal; in similar diets for treatments 2-5 soybean meal was partially substituted with 2.5; 5.0; 7.5 and $10.0 \%$ of beans in grower and 2-fold higher levels (5.0; 10.0; 15.0 and 20.0\%) in finisher, respectively. It was found that in treatments 2-4 live bodyweight at 21 days of age was higher by 3.5; 2.8 and 1.9\% in compare to control, in treatment 5 was close to that in control. Live bodyweight at 35 days in treatments 2 and 3 was higher by 3.1 and $1.3 \%$ in compare to control, in treatment 4 at the level of control, in treatment 5 lower by $3.0 \%$. Fed conversion ratio in treatments 2 and 3 was lower by $0.4 \%$ in compare to control, in treatment 4 at the level of control, in treatment 5 higher by 3.6\%; the decreased feed efficiency in treatments fed 10-20\% of beans was probably related to increased dietary levels of tannins. No significant differences between the treatments in chemical composition of breast and thigh muscles and in the concentrations of vitamins in liver were found. The conclusion was made that advisable levels of faba beans Uzunovskie in diets for broilers are $7.5 \%$ during the first 3 weeks of age and $15 \%$ during the subsequent period of growth since higher levels negatively impact growth and feed efficiency.

Keywords: faba beans, compound feeds, broilers, live bodyweight, feed conversion ratio, dietary nutrients. 